\title{
Sistem Pendukung Keputusan Menentukan Kelayakan Padi Menggunakan Metode TOPSIS dan MAUT Berbasis Web
}

\author{
Jajang Mulyana ${ }^{1}$, Arif Budimansyah Purba $^{2}$, Aprizal Wahyudi ${ }^{3}$ \\ 1,2,3 Informatika : STMIK Horizon Karawang \\ Email: ja2ngm@gmail.com
}

\begin{abstract}
The selection of the quality of rice varieties is influenced by several criteria. The most influencing criteria were plant age, plant height, shedding, average yield and yield potential. To determine the quality of rice varieties, it is very appropriate to apply a Decision Support System (DSS) in the process of providing the best solution or alternative. In the DSS, the results displayed are in the form of ratings. In this study the method used is the TOPSIS and MAUT methods. These two methods will be compared so as to produce the best alternative to determine the quality of rice varieties and find the normalized value of the matrix for each criterion. This study used 14 types of rice varieties and 5 criteria that most influence the quality of rice varieties. Each criterion has a weight that describes how important that criterion is compared to other criteria. This weighting is used to assess each alternative in order to obtain the best alternative. System testing is done by matching the results from the system with the results from experts, based on the tests carried out, the results obtained are good accuracy. With this system, researchers no longer need to repeatedly look at tables in reference books. Researchers simply type in the results of the research that are obtained in the system, then the system will process the data entered to determine the quality of the best rice varieties.
\end{abstract}

Keywords: Decision Support System, TOPSIS, MAUT, and rice varieties

\begin{abstract}
Abstrak
Pemilihan kualitas varietas padi dipengaruhi oleh beberapa kriteria. Kriteria yang paling mempengaruhi adalah umur tanaman, tinggi tanaman, kerontokan, rata-rata hasil dan potensi hasil. Untuk menentukan kualitas varietas padi sangat tepat diterapakan Sistem Pendukung Keputusan (SPK) dalam proses pemberian solusi atau alternatif terbaik. Dalam SPK hasil yang ditampilkan berupa bentuk peringkat. Dalam penelitian ini metode yang digunakan adalah metode TOPSIS dan MAUT. Kedua metode ini akan dibandingkan sehingga menghasilkan alternatif terbaik untuk menentukan kualitas varietas padi dan mencari nilai normalisasi matriks untuk setiap kriteria. Dalam penelitian ini menggunakan 14 jenis varietas padi dan 5 kriteria yang paling memperngaruhi kualitas varietas padi. Dalam setiap kriteria memiliki bobot yang menggambarkan seberapa penting kriteria tersebut dibandingkan dengan kriteria yang lain. Pembobotan ini digunakan untuk menilai setiap altenatif agar memperoleh alternatif terbaik. Pengujian sistem dilakukan dengan mencocokan hasil dari sistem dengan hasil dari pakar, berdasarkan pengujian yang dilakukan, diperoleh hasil akurasi yang baik. Dengan adanya sistem ini, peneliti tidak perlu lagi berulang-ulang melihat tabel dalam buku acuan. Peneliti cukup mengetikan hasil penelitian yang di dapat dalam sistem, kemudian sistem akan mengolah data yang dimasukan untuk menentukan kualitas varietas padi terbaik.
\end{abstract}

Kata kunci : Sistem Pendukung Keputusan, TOPSIS, MAUT, dan Varietas padi

\section{Article History :}

Received 26, Oktober, 2021

Revised 02, November, 2021

Accepted 10, November, 2021

\section{Corresponding Author:}

Nama Penulis, Jajang Mulyana

Departemen, Informatika

Instansi, STMIK Horizon Karawang

Alamat. Jl. Pangkal Perjuangan Km 1, Karawang 41361, Indonesia

Email Penulis. ja2ngm@gmail.com 


\section{Pendahuluan}

Bidang pertanian adalah salah satu sektor penting di Indonesia. Sebagian besar masyarakat Indonesia menggantungkan hidupnya pada sektor ini sebagai petani padi. Padi merupakan suatu kebutuhan pangan pokok mayoritas penduduk Indonesia sebagai sumber makanan utama. Padi termasuk dalam komoditas pangan yang banyak dibudidayakan di Indonesia. Sesuai data yang ada di Balai desa Telukjaya memiliki 14 jenis varietas padi unggul dan 5 kriteria yang paling memperngaruhi kualitas varietas padi. Tetapi banyaknya petani di desa Telukjaya yang kurang memahami kualitas bibit padi yang mengakibatkan hasil panen para petani kurang memuaskan. Banyak petani selama ini masih menggunakan cara-cara konvensional seperti coba-coba dari berbagai macam jenis varietas padi. Sehingga tidak jarang para petani harus mengalami dampak berupa tidak maksimalnya hasil panen. Oleh karena itu, dibutuhkan pengetahuan khusus mengenai varietas padi yang berkualitas agar hasil panen yang optimal ${ }^{[2]}$. Penentuan kualitas varietas padi bertujuan untuk meningkatkan produktivitas. Penggunaan bibit padi berkualitas berpengaruh besar untuk meningkatkan hasil kualitas produksi bagi petani. Selain dapat membantu pemenuhan kebutuhan pangan, penentuan bibit padi sebelum bercocok tanam juga dapat membantu kesejahteraan petani. Secara umum, pemilihan kualitas varietas padi dipengaruhi oleh beberapa kriteria. Kriteria yang paling mempengaruhi adalah umur tanaman, tinggi tanaman, kerontokan, rata-rata hasil dan potensi hasil, ketahanan tanaman padi tehadap hama dan penyakit ${ }^{[11]}$.

$$
\text { Sistem Pendukung Keputusan }
$$

(SPK) sangat tepat diterapkan dalam proses pemberian solusi dalam suatu permasalahan dalam banyak kriteria atau Multicriteria Decision Making (MDM) ${ }^{[12]}$. Dalam SPK, solusi yang ditampilkan berupa bentuk peringkat. Metode yang digunakan untuk sistem pendukung keputusan yaitu metode Technique For Order Preference By Similarity To Ideal Solution (TOPSIS) dan metode Multi Attribute Utility Theory (MAUT). Metode Topsis diperkenalkan pertama kali oleh Yoon dan Hwang padatahun 1981 untuk digunakan sebagai salah satu metode dalam memecahkan masalah multikriteria [10]. metode Topsis bertujuan untuk menentukan solusi ideal positif dan solusi ideal negatif, sedangkan metode MAUT merupakan salah satu metode yang digunakan untuk pengambilan suatu keputusan dimana metode Multi Attribute Utility Theory (MAUT) adalah suatu skema yang evaluasi akhir, $\mathrm{v}(\mathrm{x})$ dari suatu objek dijumlahkan bobot yang didefinisikan sebagai $\mathrm{x}$ dengan suatu nilai yang relevan terhadap nilai dimensinya.

Berdasarkan permasalahan di atas maka perlu adanya pembuatan suatu sistem pengambilan keputusan dalam menentukan varietas bibit padi berkualitas untuk petani di desa Telukjaya dengan menggunakan metode Technique for Order Preference by Similarity to Ideal Solution (TOPSIS) dan metode Multi Attribute Utility Theory (MAUT) yang merupakan metode pada Sistem Pendukung Keputusan (SPK). Melalui penerapan metode ini, peneliti akan membandingkan setiap jenis padi berdasarkan kriteria yang menentukan suatu padi dikatakan baik. Seperti kriteria Umur Tanaman, Tinggi Tanaman, Kerontokan dan kriteria lainnya. Sehingga akan menghasilkan sebuah informasi tentang jenis varietas padi terbaik berdasarkan semua kriteria yang ada. Melalui pembuatan sistem aplikasi berbasis web dan metode pengembangan sistem SDLC prototype diharapkan dapat membantu pengguna khususnya petani Telukjaya dalam memilih varietas padi yang akan ditanam.

\section{Tinjauan Pustaka}




\subsection{Metode Technique For Order Preference by Similarity to Ideal Solution (TOPSIS)}

TOPSIS adalah kategori Multi Criteria Decision Making (MCDM) yaitu teknik pengambilan keputusan dari beberapa pilihan alternatif yang ada, khususnya MADC (Multi Attribute Decision Making). Menurut Hwang [7], menyatakan bahwa: "Topsis menggunakan prinsip bahwa alternatif yang terpilih harus mempunyai jarak terdekat dari solusi ideal positif dan jarak terpanjang (terjauh) dari solusi ideal negatif dari sudut pandang geometris dengan menggunakan jarak Eucliden (jarak antara dua titik) untuk menentukan kedekatan relatif dari suatu alternatif dengan solusi optimal. Solusi ideal positif didefenisikan sebagai jumlah dari seluruh nilai terbaik yang dapat dicapai untuk setiap atribut, sedangkan solusi negatif-ideal terdiri dari seluruh nilai terburuk yang dicapai untuk setiap atribut. TOPSIS mempertimbangkan keduanya, jarak terhadap solusi ideal negatif dengan mengambil kedekatan relative terhadap solusi ideal positif.

\subsection{Tahapan TOPSIS}

Langkah-langkah yang dilakukan dalam menyelesaikan suatu permasalahan menggunakan metode TOPSIS adalah sebagai berikut ${ }^{[7]}$ :

1. Normalisasi Matriks

Setiap elemen pada matriks D dinormalisasikan untuk mendapatkan matriks normalisasi $\mathrm{R}$.

2. Pembobotan pada matriks yang telah dinormalisasikan.

Diberikan bobot $w=\left(w_{1}, w_{2}, \ldots, \mathrm{W}_{n}\right)$, sehingga weighted normalized matrix D dapat dihasilkan sebagai berikut :

$$
D=\begin{array}{lll}
w_{1} r_{11} & w_{2} r_{12} & w_{n} r_{1 n} \\
w_{1} r_{21} & w_{2} r_{22} & w_{n} r_{r 2 n} \vee \\
w_{1} r_{m 1} & w_{2} r_{m 2} & w_{n} r_{m n}
\end{array}
$$

3. Menentukan solusi ideal positif dan solusi ideal negatif. Penentuan solusi ideal ditunjukkan pada persamaan.

4. Separation measure ini merupakan pengukuran jarak dari suatu alternatif ke solusi ideal positif dan solusi ideal negatif.

5. Menghitung kedekatan relatif dengan ideal positif dan ideal negatif.

6. Merangking alternatif-alternatif dapat dirangking berdasarkan urutan $\mathrm{Ci}$. Maka dari itu, alternatif terbaik adalah salah satu yang berjarak terpendek terhadap solusi ideal dan berjarak terjauh dengan solusi negatif-ideal.

\subsection{Metode Multy Attribute Utility Theory (MAUT) \\ Multi Attribute Utility Theory} (MAUT) merupakan salah satu metode yang digunakan untuk pengambilan suatu keputusan dimana metode Multi Attribute Utility Theory (MAUT) adalah suatu skema yang evaluasi akhir, $\mathrm{v}(\mathrm{x})$ dari suatu objek dijumlahkan bobot yang didefinisikan sebagai $\mathrm{x}$ dengan suatu nilai yang relevan terhadap nilai dimensinya. Ungkapan yang biasa digunakan untuk menyebutnya adalah nilai utilitas. Metode MAUT digunakan untuk merubah dari beberapa kepentingan kedalam nilai numerik dengan skala 0-1 dengan 0 mewakili pilihan terburuk dan 1 terbaik.

Hasil akhir dari metode MAUT merupakan suatu urutan peringkat yang dihasilkan melalui evaluasi gambaran dari para pembuat keputusan, dimana nilai evaluasi didefinisikan pada persamaan : $V(x) \sum=1 w_{j} . x_{i j}$. Dimana $V(x)$ merupakan nilai evaluasi dari sebuah objek ke $i$ dan $w i$ merupakan bobot yang menentukan nilai dari seberapa penting elemen ke $i$ terhadap elemen lainnya. Sedangkan $n$ merupakan jumlah elemen. Total dari bobot adalah 1 .

$$
\sum=1 w_{i}=1
$$

\section{Metode Penelitian}

3.1 Proses Pembobotan 
Proses pembobotan menggunakan metode TOPSIS dan MAUT. Memberikan bobot kriteria masing-masing dan sub kriteria dengan menggunakan interval 0-1 untuk masing-masing kriteria dengan prioritas terpenting.

A. Standar penilaian Umur Tanaman

Tabel 3.1 Standar penilaian umur tanaman

\begin{tabular}{clcc}
\hline No & Parameter & Nilai & Bobot \\
\hline 1 & $90-100$ Hari & 1 & \\
2 & $101-111$ Hari & 2 & \\
3 & $112-122$ Hari & 3 & 8 \\
4 & $123-133$ Hari & 4 & \\
5 & $134-144$ Hari & 5 & \\
\hline
\end{tabular}

B. Standar penilaian Tinggi Tanaman Tabel 3.2 Standar penilaian tinggi tanaman

\begin{tabular}{clrc}
\hline No & Parameter & Nilai & Bobot \\
\hline 1 & $70-80 \mathrm{~cm}$ & 1 & \\
2 & $81-91 \mathrm{~cm}$ & 2 & \\
3 & $92-102 \mathrm{~cm}$ & 3 & 7 \\
4 & $103-113 \mathrm{~cm}$ & 4 & \\
5 & $114-124 \mathrm{~cm}$ & 5 & \\
\hline
\end{tabular}

C. Standar penilaian Kerontokan Tabel 3.3 Standar penilaian kerontokan

\begin{tabular}{clcc}
\hline No & Parameter & Nilai & Bobot \\
\hline 1 & Mudah Rontok & 1 & \\
2 & Rontok & 2 & \\
3 & Sedang & 3 & 7 \\
4 & Agak Tahan & 4 & \\
5 & Tahan & 5 & \\
\hline
\end{tabular}

D. Standar penilaian Rata-rata Hasil

Tabel 3.4 Standar penilaian rata-rata hasil

\begin{tabular}{cccc}
\hline No & Parameter & Nilai & Bobot \\
\hline 1 & $4.5-55 \mathrm{t} / \mathrm{ha}$ & 1 & \\
2 & $5.6-6.6 \mathrm{t} / \mathrm{ha}$ & 2 & \\
3 & $6.7-7.7 \mathrm{t} / \mathrm{ha}$ & 3 & 8 \\
4 & $7.8-8.8 \mathrm{t} / \mathrm{ha}$ & 4 & \\
5 & $8.9-9.9 \mathrm{t} / \mathrm{ha}$ & 5 & \\
\hline
\end{tabular}

E. Standar penilaian Potensi Hasil

Tabel 3.4 Standar penilaian potensi hasil

\begin{tabular}{clcc}
\hline No & Parameter & Nilai & Bobot \\
\hline 1 & $5.0-6.0 \mathrm{t} / \mathrm{ha}$ & 1 & \\
2 & $6.1-7.1 \mathrm{t} / \mathrm{ha}$ & 2 & \\
3 & $7.2-8.2 \mathrm{t} / \mathrm{ha}$ & 3 & 6 \\
4 & $9.4-10.4 \mathrm{t} / \mathrm{ha}$ & 4 & \\
5 & $10.5-11.5 \mathrm{t} / \mathrm{ha}$ & 5 & \\
\hline
\end{tabular}

\subsection{Model Prototype}

Metode penelitian yang digunakan dalam membangun sistem ini adalah Prototype. Yang mengusulkan pendekatan kepada perangkat lunak sistematik dan berulang yang dimulai dari Communication, Quick Plan, Modelling Quick Design, Construction of Prototype, Deployment Deliveryv and Feed Back ${ }^{[9]}$.

\section{A. Tahapan TOPSIS}

1. Matriks Keputusan Ternormalisasi (R) TOPSIS membutuhkan ranking kinerja setiap alternatif $A i$ pada setiap kriteria $C j$ yang ternormalisasi yaitu :

$$
r_{i j}=\frac{x_{i j}}{\sqrt{\sum_{i=1}^{m} x_{i j}^{2}}}
$$

2. Matriks Keputusan Ternormalisasi Terbobot (Y)

Nilai dari masing-masing data ternormalisasi (R) kemudian dikalikan dengan bobot (W) untuk mendapatkan matriks keputusan ternormalisasi terbobot (Y).

$$
y_{i j}=w_{j} \cdot r_{i j}
$$

3. Matriks Solusi Ideal Positif (A+) dan Negatif (A-)

Solusi ideal positif $\mathrm{A}+$ dan solusi ideal negatif A- dapat ditentukan berdasarkan ranking bobot ternormalisasi (yij).

\section{- Solusi Ideal Positif A+}

Persamaan yang digunakan untuk menentukan solusi ideal positif adalah :

$$
A^{+}=\left\{\left(\max y_{i j} \mid j \in J\right),\left(\min y_{i j} \mid j \in J^{\prime}\right), i=1,2,3, \ldots, m\right\}
$$

- Solusi Ideal Negatif A-

Persamaan yang digunakan untuk menentukan solusi ideal negatif adalah:

$$
A^{-}=\left\{\left(\min y_{i j} \mid j \in J\right),\left(\max y_{i j} \mid j \in J^{\prime}\right), i=1,2,3, \ldots, m\right\}
$$

4. Jarak Solusi Ideal Positif/Negatif (D)

Menghitung separasi, Di adalah jarak (dalam pandangan Euclidean) alternatif dari solusi ideal positif. Sedangkan $\boldsymbol{D i}$ adalah jarak (dalam pandangan Euclidean) alternatif dari solusi ideal negatif.

- Jarak antara Alternatif Ai dengan Solusi Ideal Positif (D+)

$$
D_{i}^{+}=\sqrt{\sum_{j=1}^{n}\left(y_{i}^{+}-y_{i j}\right)^{2}}
$$

- Jarak antara Alternatif Ai dengan Solusi Ideal Negatif (D-)

$$
D_{i}^{-}=\sqrt{\sum_{j=1}^{n}\left(y_{i j}-y_{j}^{-}\right)^{2}}
$$

\subsection{Metode TOPSIS}




\section{Nilai Preferensi (V)}

Nilai preferensi untuk setiap alternatif $(V i)$ diberikan sebagai :

$$
V_{i}=\frac{D_{i}^{-}}{D_{i}^{-}+D_{i}^{+}}
$$

\subsection{Metode MAUT}

\section{A. Tahapan MAUT}

1. Pecah sebuah keputusan ke dalam dimensi yang berbeda

2. Tentukan bobot relatif pada masingmasing dimensi

3. Daftar semua alternative

4. Menghitung nilai Utility normalisasi matriks untuk masing-masing alternatif sesuai atributnya.

$$
\begin{aligned}
& (x-X i) \\
& U(x)=\frac{x-x_{i}}{x i-x i}
\end{aligned}
$$

\section{Keterangan}

$$
\begin{array}{ll}
U(X) & =\text { Normalisasi bobot Alternatif } \\
x i- & =\text { Nilai kriteria minimal ( bobot terburuk ) } \\
x i+ & =\text { Nilai kriteria maksimal ( bobot terbaik) } \\
x & =\text { bobot alternative }
\end{array}
$$

\begin{tabular}{|c|c|c|}
\hline No & Tahapan & Teknik \\
\hline 1 & Mendengarkan & $\begin{array}{l}\text { Menemukan solusi dari pertanyaan- } \\
\text { pertanyaan yang bertujuan untuk } \\
\text { menyelesaikan masalah yang } \\
\text { sedang terjadi untuk saat ini. }\end{array}$ \\
\hline 2 & $\begin{array}{l}\text { Persiapan sebelum } \\
\text { melakukan } \\
\text { komunikasi }\end{array}$ & $\begin{array}{l}\text { Mempersiapkan pertanyaan yang } \\
\text { berkaitan dengan masalah yang } \\
\text { sedang terjadi dan melakukan } \\
\text { wawancara dihari yang sudah } \\
\text { diagendakan. }\end{array}$ \\
\hline 3 & $\begin{array}{l}\text { Menjadi fasilitator } \\
\text { aktivitas komunikasi }\end{array}$ & $\begin{array}{l}\text { Melakukan wawancara kepada } \\
\text { Petugas/Pakar Pertanian }\end{array}$ \\
\hline 4 & $\begin{array}{l}\text { Komunikasi } \\
\text { dilakukan secara } \\
\text { tatap muka }\end{array}$ & $\begin{array}{l}\text { Melakukan wawancara kepada } \\
\text { Petugas/Pakar Pertanian } \\
\text { melakukan evaluasi. }\end{array}$ \\
\hline 5 & $\begin{array}{l}\text { Melakukan } \\
\text { pencatatan dan } \\
\text { dokumentasi }\end{array}$ & $\begin{array}{l}\text { Mencatat semua data yang dianggap } \\
\text { penting, } \\
\text { hardcopy/softcopy } \text { meminta } \\
\text { memungkinkan. }\end{array}$ \\
\hline 6 & $\begin{array}{l}\text { Kerjasama dengan } \\
\text { pihak yang terkait }\end{array}$ & $\begin{array}{l}\text { Bekerjasama dalam membangun } \\
\text { aplikasi Sistem Pendukung } \\
\text { Keputusan Menentukan Kelayakan } \\
\text { Padi Berbasis Web, menerapkan } \\
\text { metode SDLC Prototype, dan } \\
\text { menggunakan bahasa pemrograman }\end{array}$ \\
\hline
\end{tabular}

5. Kalikan utility dengan bobot untuk

\begin{tabular}{|c|c|c|}
\hline No & Tahapan & Teknik \\
\hline & & $\begin{array}{lccc}\text { PHP } & 7.2 & \text { serta } & \text { penyimpanan } \\
\text { database di } & M y S O L & \end{array}$ \\
\hline 7 & $\begin{array}{l}\text { Melakukan } \\
\text { modularisasi }\end{array}$ & $\begin{array}{l}\text { Aktivitas observasi sekaligus } \\
\text { berdiskusi bertujuan untuk } \\
\text { pengembangan aplikasi yang akan } \\
\text { dibuat. }\end{array}$ \\
\hline 8 & $\begin{array}{l}\text { Membuat } \\
\text { sketsa/gambar }\end{array}$ & $\begin{array}{lrr}\text { Analisis } & \text { sistem } & \text { berjalan } \\
\text { digambarkan } & \text { dalam } & \text { bentuk }\end{array}$ \\
\hline & sistem berjalan & $\begin{array}{l}\text { flowchart dan dideskripsikan dalam } \\
\text { tabel. }\end{array}$ \\
\hline 9 & $\begin{array}{l}\text { Membuat } \\
\text { kesepakatan } \\
\text { mengenai fitur-fitur } \\
\text { perangkat lunak }\end{array}$ & $\begin{array}{l}\text { Melakukan wawancara lanjutan dan } \\
\text { mendiskusikan fitur-fitur yang akan } \\
\text { digunakan pada aplikasi Sistem } \\
\text { Pendukung Keputusan Menentukan }\end{array}$ \\
\hline & & $\begin{array}{l}\text { Kelayakan Padi menggunakan } \\
\text { metode TOPSIS dan MAUT } \\
\text { Berbasis Web }\end{array}$ \\
\hline 10 & Negosiasi & $\begin{array}{l}\text { Menjelaskan fungsi-fungsi tertentu } \\
\text { apa saja yang akan berjalan didalam } \\
\text { aplikasi dan membuat persetujuan } \\
\text { mengenai penyerahan aplikasi } \\
\text { nantinya sesuai jadwal yang sudah } \\
\text { direncanakan. }\end{array}$ \\
\hline
\end{tabular}
menemukan nilai masing-masing alternatif.

\section{Hasil Dan Pembahasan}

\subsection{Communication (Komunikasi)}

\begin{tabular}{|c|c|c|}
\hline No & Tahapan & Teknik \\
\hline 1 & $\begin{array}{l}\text { Memahami lingkup } \\
\text { proyek }\end{array}$ & $\begin{array}{l}\text { Membuat manajemen tentang } \\
\text { Sistem Pendukung Keputusan } \\
\text { Menentukan Kelayakan Padi } \\
\text { Berbasis Web (roadmap) Sistem } \\
\text { Pendukung Keputusan } \\
\text { Menentukan Kelayakan Padi } \\
\text { menggunakan metode TOPSIS } \\
\text { dan MAUT Berbasis Web }\end{array}$ \\
\hline 2 & $\begin{array}{l}\text { Melibatkan } \\
\text { stakeholder } \\
\text { aktivitas } \\
\text { perencanaan }\end{array}$ & $\begin{array}{l}\text { Mendefinisikan prioritas dan } \\
\text { menetapkan batasan-batasan } \\
\text { proyek perangkat lunak sebagai } \\
\text { berikut : Aplikasi yang dikelola } \\
\text { hanya } 1 \text { lingkup dengan aktor } \\
\text { yang terlibat sebanyak 1orang } \\
\text { yaitu Pakar pertanian. }\end{array}$ \\
\hline 3 & Perencanaan iteratif & $\begin{array}{l}\text { Melakukan desain (rancangan) } \\
\text { ulang apabila perangkat lunak } \\
\text { yang dibangun belum selesai. }\end{array}$ \\
\hline 4 & $\begin{array}{l}\text { Melakukan } \\
\text { prakiraan siklus } \\
\text { hidup manajemen } \\
\text { proyek }\end{array}$ & $\begin{array}{l}\text { Melakukan negosiasi lingkup } \\
\text { proyek agar tim dapat } \\
\text { memperkirakan indikasi produk, } \\
\text { kualitas, waktu, biaya, dan } \\
\text { sumber daya tentang aplikasi } \\
\text { Sistem Pendukung Keputusan } \\
\text { Menentukan Kelayakan Padi } \\
\text { Berbasis Web }\end{array}$ \\
\hline 5 & $\begin{array}{l}\text { Mempertimbangkan } \\
\text { risiko }\end{array}$ & $\begin{array}{l}\text { Memperkirakan durasi dari tugas } \\
\text { (summary task) yang ada pada } \\
\text { roadmap dalam } \\
\text { mempertimbangkan resiko. }\end{array}$ \\
\hline 6 & $\begin{array}{l}\text { Bersikap realistis } \\
\text { terhadap } \\
\text { pembangunan } \\
\text { perangkat lunak }\end{array}$ & $\begin{array}{l}\text { Memperkirakan penyelesaian } \\
\text { setiap langkah dalam } \\
\text { membangun perangkat lunak }\end{array}$ \\
\hline 7 & $\begin{array}{l}\text { Menyesuaikan } \\
\text { tingkat granularity }\end{array}$ & $\begin{array}{l}\text { Mengindentifikasi data pada } \\
\text { tabel yang akan digunakan } \\
\text { dalam perangkat lunak. }\end{array}$ \\
\hline 8 & $\begin{array}{l}\text { Perencanaan } \\
\text { jaminan kualitas }\end{array}$ & $\begin{array}{l}\text { Membangun aplikasi untuk } \\
\text { mempermudah Petugas dalam }\end{array}$ \\
\hline
\end{tabular}

Tabel 4.1 Hasil Tahapan Communication

\subsection{Quick Plan (Perancangan Secara Cepat)}

Tabel 4.2 Hasil Tahapan Quick Plan

Jurnal Interkom: Jurnal Publikasi Ilmiah Bidang Teknologi Informasi dan Komunikasi

Volume 16 Nomor 03 Bulan Oktober - Tahun 2021 


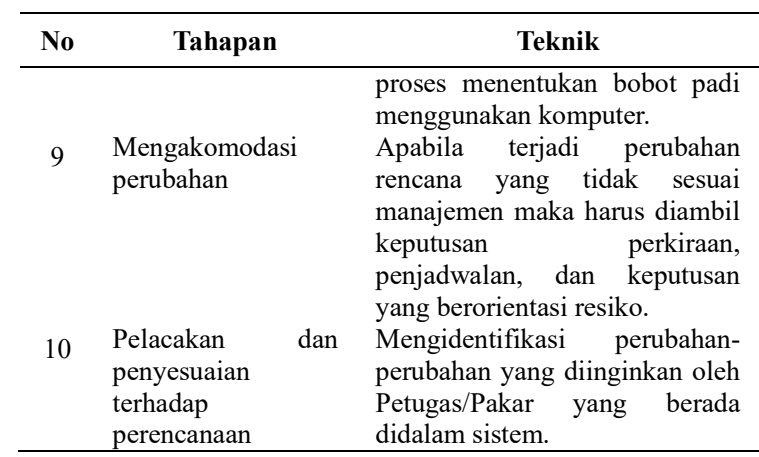

4.3. Modeling Quick Design (Pemodelan Perancangan Secara Cepat)

4.3.1. Analisis Sistem Berjalan

A. Analisis Teori

1. Metode TOPSIS

\subsection{Data Kriteria}

Tabel 4.3 Bobot Kriteria

\begin{tabular}{clccc}
\hline Kode & \multicolumn{1}{c}{ Kriteria } & Atribut & Bobot & Normalisasi \\
\hline C1 & Umur Tanaman & Benefit & 8 & 0.22 \\
C2 & Tinggi Tanaman & Benefit & 7 & 0.19 \\
C3 & Kerontokan & Benefit & 7 & 0.19 \\
C4 & Rata-rata Hasil & Benefit & 8 & 0.22 \\
C5 & Potensi Hasil & Benefit & 6 & 0.17 \\
\hline
\end{tabular}

\subsection{Hasil Analisa}

\section{A. Data Alternatif}

Tabel 4.4 Data Alternatif

\begin{tabular}{llccccc}
\hline Kode & Nama Varieasi & C1 & C2 & C3 & C4 & C5 \\
\hline A01 & IR 36 & 2 & 4 & 5 & 5 & 2 \\
A02 & Silugonggo & 8 & 1 & 5 & 5 & 2 \\
A03 & Cibodas & 8 & 7 & 5 & 5 & 2 \\
A04 & Digal & 8 & 6 & 5 & 2 & 2 \\
A05 & Cimalaya & 8 & 8 & 7 & 5 & 2 \\
A06 & Tuket Petuna & 5 & 1 & 2 & 3 & 2 \\
A07 & Sunggal & 5 & 4 & 5 & 3 & 4 \\
A08 & Batang Gadis & 3 & 1 & 5 & 5 & 4 \\
A09 & Angke & 3 & 3 & 1 & 5 & 4 \\
A10 & Cisadane & 1 & 1 & 5 & 4 & 2 \\
A11 & Maro & 3 & 5 & 5 & 5 & 5 \\
A12 & Rokan & 3 & 1 & 5 & 5 & 3 \\
A13 & Hipa 3 & 3 & 5 & 5 & 5 & 5 \\
A14 & Hipa 4 & 3 & 4 & 2 & 1 & 1 \\
\hline
\end{tabular}

\subsection{Normalisasi Matriks Keputusan}

A01 $=$ Alternatif $^{\wedge} 2=4$; Seterusnya

Tabel 4.5 Normalisasi Matriks Keputusan

\begin{tabular}{ccccccc}
\hline No & Alternatif & C1 & C2 & C3 & C4 & C5 \\
\hline 1 & A01 & 4 & 16 & 25 & 25 & 4 \\
2 & A02 & 25 & 1 & 25 & 25 & 4 \\
3 & A03 & 25 & 16 & 25 & 25 & 4 \\
4 & A04 & 25 & 9 & 25 & 4 & 4 \\
5 & A05 & 25 & 25 & 16 & 25 & 4 \\
6 & A06 & 25 & 1 & 4 & 9 & 4 \\
7 & A07 & 25 & 16 & 25 & 9 & 16 \\
8 & A08 & 9 & 1 & 25 & 25 & 16 \\
9 & A09 & 9 & 9 & 1 & 25 & 16 \\
10 & A10 & 1 & 1 & 25 & 16 & 4 \\
11 & A11 & 9 & 25 & 25 & 25 & 25 \\
12 & A12 & 9 & 1 & 25 & 25 & 9
\end{tabular}

\begin{tabular}{ccccccc}
\hline No & Alternatif & C1 & C2 & C3 & C4 & C5 \\
\hline 13 & A13 & 9 & 25 & 25 & 25 & 25 \\
14 & A14 & 9 & 25 & 4 & 1 & 1 \\
\hline
\end{tabular}

Selanjutnya setiap alternatif dari masingmasing kriteria dijumlahkan. Setelah selesai perhitungan normalisasi matriks keputusan setiap alternatif dihitung akar dari jumlah setiap alternatif.

\begin{tabular}{cccccc}
\hline & C1 & C2 & C3 & C4 & C5 \\
\hline Jumlah & 209 & 162 & 275 & 264 & 136 \\
\hline $\begin{array}{c}\text { Hasil Akar } \\
\text { Normalisasi }\end{array}$ & 14.46 & 13.08 & 16.58 & 16.25 & 11.66 \\
\hline
\end{tabular}

\subsection{Normalisasi Terbobot}

Normalisasi terbobot yaitu data ((normalisasi matriks keputusan / hasil akar normalisasi matriks keputusan) * Normalisasi bobot masing-masing kriteria).

Alternatif A01 $=((4 / 14.46 * 0.22)=\mathbf{0 . 0 6}$ dan Seterusnya

Tabel 4.6 Normalisasi Terbobot

\begin{tabular}{ccccccc}
\hline No & Alternatif & C1 & C2 & C3 & C4 & C5 \\
\hline 1 & A01 & 0.06 & 0.24 & 0.29 & 0.34 & 0.06 \\
2 & A02 & 0.38 & 0.01 & 0.29 & 0.34 & 0.06 \\
3 & A03 & 0.38 & 0.24 & 0.29 & 0.34 & 0.06 \\
4 & A04 & 0.38 & 0.13 & 0.29 & 0.05 & 0.06 \\
5 & A05 & 0.38 & 0.37 & 0.29 & 0.34 & 0.06 \\
6 & A06 & 0.38 & 0.01 & 0.05 & 0.12 & 0.06 \\
7 & A07 & 0.38 & 0.24 & 0.29 & 0.12 & 0.23 \\
8 & A08 & 0.14 & 0.01 & 0.29 & 0.34 & 0.23 \\
9 & A09 & 0.14 & 0.13 & 0.01 & 0.34 & 0.23 \\
10 & A10 & 0.02 & 0.01 & 0.29 & 0.22 & 0.06 \\
11 & A11 & 0.14 & 0.37 & 0.29 & 0.34 & 0.36 \\
12 & A12 & 0.14 & 0.01 & 0.29 & 0.34 & 0.13 \\
13 & A13 & 0.14 & 0.37 & 0.29 & 0.34 & 0.36 \\
14 & A14 & 0.14 & 0.37 & 0.05 & 0.01 & 0.01 \\
\hline
\end{tabular}

\subsection{Matriks Ideal Positif Dan Ideal Negatif}

$\mathbf{A}+=(0.38-0.06)^{\wedge} 2+(0.37-0.24)^{\wedge} 2+$ $(0.29-0.29)^{\wedge} 2+(0.34-0.34)^{\wedge} 2+(0.36-$ $0.06)^{\wedge} 2=\mathbf{1 . 2 1}$

$$
\begin{aligned}
& \mathbf{A}-=(0.06-0.02)^{\wedge} 2+(0.24-0.01)^{\wedge} 2+ \\
& (0.29-0.01)^{\wedge} 2+(0.34-0.01)^{\wedge} 2+(0.06- \\
& 0.01)^{\wedge} 2=\mathbf{0 . 2 0}
\end{aligned}
$$

Tabel 4.7 Matriks Ideal Positif Dan Ideal Negatif

\begin{tabular}{cccc}
\hline No & Alternatif & Positif & Negatif \\
\hline 1 & A01 & 1,21 & 0,20 \\
2 & A02 & 1,07 & 0,50 \\
3 & A03 & 0,73 & 0,71 \\
4 & A04 & 0,86 & 0,51 \\
5 & A05 & 0,64 & 1,08 \\
6 & A06 & 1,30 & 0,34 \\
7 & A07 & 0,78 & 0,45
\end{tabular}




\begin{tabular}{cccc}
\hline No & Alternatif & Positif & Negatif \\
\hline 8 & A08 & 0,95 & 0,30 \\
9 & A09 & 0,87 & 0,34 \\
10 & A10 & 1,41 & 0,11 \\
11 & A11 & 0,13 & 1,33 \\
12 & A12 & 0,72 & 0,41 \\
13 & A13 & 0,17 & 1,07 \\
14 & A14 & 1,11 & 0,46 \\
\hline
\end{tabular}

\subsection{Nilai Preferensi}

Menghitung kedekatan relatif terhadap solusi ideal positif dan solusi ideal negatif Menghitung nilai Preferensi dengan cara : ((jarak alternatif negatif / (jarak alternatif positif + jarak alternatif negatif).

$$
\mathbf{V}=(0.20 /(1.21+0.20))=\mathbf{0 . 1 4}
$$

Tabel 4.8 Hasil Nilai Preferensi

\begin{tabular}{ccccc}
\hline No & Alternatif & Positif & Negatif & Preferensi \\
\hline 1 & A01 & 0,21 & 0,24 & 0.53 \\
2 & A02 & 0,22 & 0,32 & 0.60 \\
3 & A03 & 0,11 & 0,37 & 0.78 \\
4 & A04 & 0,23 & 0,23 & 0.50 \\
5 & A05 & 0,10 & 0,40 & 0.80 \\
6 & A06 & 0,33 & 0,15 & 0.32 \\
7 & A07 & 0,08 & 0,32 & 0.80 \\
8 & A08 & 0,20 & 0,25 & 0.55 \\
9 & A09 & 0,21 & 0,18 & 0.46 \\
10 & A10 & 0,37 & 0,12 & 0.25 \\
11 & A11 & 0,06 & 0,45 & 0.88 \\
12 & A12 & 0,24 & 0,22 & 0.47 \\
13 & A13 & 0,06 & 0,45 & 0.88 \\
14 & A14 & 0,35 & 0,14 & 0.29 \\
\hline
\end{tabular}

\section{Metode MAUT}

\subsection{Bobot Kriteria}

Tabel 4.9 Bobot Kriteria

\begin{tabular}{clccc}
\hline Kode & \multicolumn{1}{c}{ Kriteria } & Atribut & Bobot & Normalisasi \\
\hline C1 & Umur Tanaman & Benefit & 8 & 0.22 \\
C2 & Tinggi & Benefit & 7 & 0.19 \\
& Tanaman & & & \\
C3 & Kerontokan & Benefit & 7 & 0.19 \\
C4 & Rata-rata Hasil & Benefit & 8 & 0.22 \\
C5 & Potensi Hasil & Benefit & 6 & 0.17 \\
\hline
\end{tabular}

\subsection{Hasil Analisa}

\section{A. Data Alternatif}

Tabel 4.10 Data Alternatif

\begin{tabular}{clccccc}
\hline Kode & Nama Varieasi & C1 & C2 & C3 & C4 & C5 \\
\hline A01 & IR 36 & 2 & 4 & 5 & 5 & 2 \\
A02 & Silugonggo & 5 & 1 & 5 & 5 & 2 \\
A03 & Cibodas & 5 & 4 & 5 & 5 & 2 \\
A04 & Digal & 5 & 3 & 5 & 2 & 2 \\
A05 & Cimalaya & 5 & 5 & 4 & 5 & 2 \\
A06 & Tuket Petuna & 5 & 1 & 2 & 3 & 2 \\
A07 & Sunggal & 5 & 4 & 5 & 3 & 4 \\
A08 & Batang Gadis & 3 & 1 & 5 & 5 & 4 \\
A09 & Angke & 3 & 3 & 1 & 5 & 4 \\
A10 & Cisadane & 1 & 1 & 5 & 4 & 2 \\
A11 & Maro & 3 & 5 & 5 & 5 & 5 \\
A12 & Rokan & 3 & 1 & 5 & 5 & 3 \\
A13 & Hipa 3 & 3 & 5 & 5 & 5 & 5 \\
A14 & Hipa 4 & 3 & 4 & 2 & 1 & 1 \\
\hline
\end{tabular}

Nilai Max dan Min

\begin{tabular}{cccccc}
\hline Nilai & C1 & C2 & C3 & C4 & C5 \\
\hline Nilai Min & 1 & 1 & 1 & 1 & 1 \\
Nilai Max & 5 & 5 & 5 & 5 & 5 \\
\hline
\end{tabular}

\subsection{Normalisasi Matriks Keputusan}

$$
U_{(x)}=\frac{x-x i^{-}}{x i^{+}-x i^{-}}
$$

Keterangan :

$\begin{array}{ll}U_{(x)} & : \text { Normalisasi Bobot Alternatif } \mathrm{x} \\ x & : \text { Bobot Alternatif } \\ x i^{-} & : \text {Bobot Terburuk (minimum) dari kriteria ke-x } \\ x i^{+} & : \text {Bobot Terbaik (Maksimum) dari kriteria ke-X }\end{array}$

\subsection{Matriks Ternormalisasi}

\section{A01- IR 36}

$$
\begin{aligned}
& \mathrm{C} 1=((2-1) /(5-1))=0.25 \\
& \mathrm{C} 2=((4-1) /(5-1))=0.75 \\
& \mathrm{C} 3=((5-1) /(5-1))=1.00 \\
& \mathrm{C} 4=((5-1) /(5-1))=1.00 \\
& \mathrm{C} 5=((2-1) /(5-1))=0.25
\end{aligned}
$$

Tabel 4.11 Hasil Matriks Ternormalisasi

\begin{tabular}{clccccc}
\hline No & Alternatif & C1 & C2 & C3 & C4 & C5 \\
\hline 1 & IR 36 & 0.25 & 0.75 & 1.00 & 1.00 & 0.25 \\
2 & Silugonggo & 1.00 & 0.00 & 1.00 & 1.00 & 0.25 \\
3 & Cibodas & 1.00 & 0.75 & 1.00 & 1.00 & 0.25 \\
4 & Digal & 1.00 & 0.50 & 1.00 & 0.25 & 0.25 \\
5 & Cimalaya & 1.00 & 1.00 & 0.75 & 1.00 & 0.25 \\
6 & Tuket Petuna & 1.00 & 0.00 & 0.25 & 0.50 & 0.25 \\
7 & Sunggal & 1.00 & 0.75 & 1.00 & 0.50 & 0.75 \\
8 & Batang Gadis & 0.50 & 0.00 & 1.00 & 1.00 & 0.75 \\
9 & Angke & 0.50 & 0.50 & 0.00 & 1.00 & 0.75 \\
10 & Cisadane & 0.00 & 0.00 & 1.00 & 0.75 & 0.25 \\
11 & Maro & 0.50 & 1.00 & 1.00 & 1.00 & 1.00 \\
12 & Rokan & 0.50 & 0.00 & 1.00 & 1.00 & 0.50 \\
13 & Hipa 3 & 0.50 & 1.00 & 1.00 & 1.00 & 1.00 \\
14 & Hipa 4 & 0.50 & 1.00 & 0.25 & 0.00 & 0.00 \\
\hline
\end{tabular}

\subsection{Hasil Rangking}

$$
V(X) \sum_{i=1}^{n} W j . X i j
$$

$\mathbf{A 0 1}=(0.22 * 0.25)+(0.19 * 0.75)+(0.19 * 0.1 .00)+$ $(0.22 * 1.00)+(0.17 * 0.25)=0.66$

Tabel 4.12 Hasil Perangkingan

\begin{tabular}{clcl}
\hline No & \multicolumn{1}{c}{ Alternatif } & Hasil & \multicolumn{1}{c}{ Keputusan } \\
\hline 1 & IR 36 & 0.66 & Kualitas Super \\
2 & Silugonggo & 0.68 & Kualitas Super \\
3 & Cibodas & 0.83 & Kualitas Super \\
4 & Digal & 0.61 & Kualitas Sedang \\
5 & Cimalaya & 0.83 & Kualitas Super
\end{tabular}




\begin{tabular}{clcl}
\hline No & Alternatif & Hasil & \multicolumn{1}{c}{ Keputusan } \\
\hline 6 & Tuket Petuna & 0.42 & Kualitas Rendah \\
7 & Sunggal & 0.80 & Kualitas Super \\
8 & Batang Gadis & 0.65 & Kualitas Sedang \\
9 & Angke & 0.56 & Kualitas Sedang \\
10 & Cisadane & 0.40 & Kualitas Rendah \\
11 & Maro & 0.89 & Kualitas Super \\
12 & Rokan & 0.61 & Kualitas Sedang \\
13 & Hipa 3 & 0.89 & Kualitas Super \\
14 & Hipa 4 & 0.35 & Kualitas Rendah \\
\hline
\end{tabular}

\section{B. Analisis Sistem}

\section{Flowchart}

\subsection{Flowchart Data Alternatif}

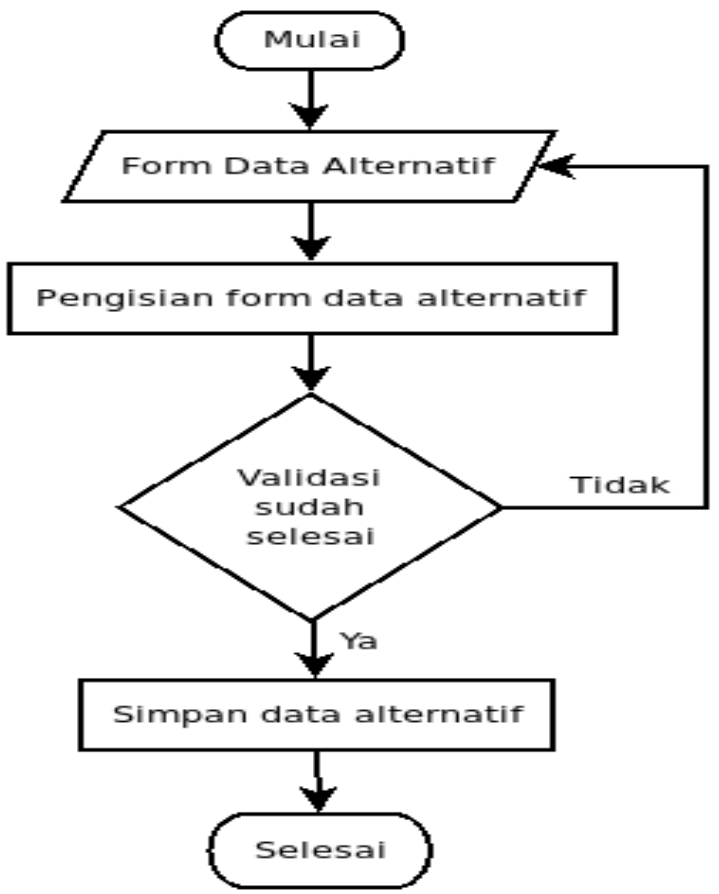

Gambar 3.1 Flowchart Data Alternatif

\subsection{Deskripsi Flowchart Data Alternatif}

\section{Tabel 4.13 Deskripsi Flowchart Data Alternatif}

\begin{tabular}{cll}
\hline No & \multicolumn{1}{c}{ Tahapan } & \multicolumn{1}{c}{ Deskripsi } \\
\hline 1 & $\begin{array}{l}\text { Mengisi form data } \\
\text { alternatif }\end{array}$ & $\begin{array}{l}\text { Pengisian form data alternatif dilakukan } \\
\text { oleh petugas bagian pertanian dan } \\
\text { kelengkapan data alternatif }\end{array}$ \\
2 Validasi pengisian \\
kelengkapan data \\
alternatif
\end{tabular}

\begin{tabular}{ccc}
\hline No & Tahapan & Deskripsi \\
\hline 4 & $\begin{array}{l}\text { Simpan dokumen } \\
\text { data alternatif baru }\end{array}$ & Data alternatif kemudian disimpan.
\end{tabular}

\subsubsection{Analisis Sistem Ajuan (Object Orientied Approach)}

System Activities (Usecase

Description and actor, Scenario dan Usecase Diagram), System Activities merupakan proses pemaparan dari:

\section{A. Deskripsi Aktor}

\begin{tabular}{ccc}
\multicolumn{3}{c}{ Tabel 4.14 Deskripsi Aktor } \\
\hline No & Aktor & \multicolumn{1}{c}{ Deskripsi } \\
\hline 1 & Admin & $\begin{array}{l}\text { Adalah orang yang menggunakan aplikasi } \\
\text { sistem dan mempunyai hak akses }\end{array}$ \\
\hline 2 & Pengguna & $\begin{array}{l}\text { Adalah orang yang menggunakan aplikasi } \\
\text { sistem dan tidak memiliki hak akses untuk } \\
\text { mengakses dan memodifikasi sistem }\end{array}$ \\
\hline
\end{tabular}

\section{B. Deskripsi UseCase}

Use Case sebagai pembuatan sistem ajuan terdiri dari 8 usecase utama, deskripsi seperti yang ada dibawah ini:

Tabel 4.15 Deskripsi UseCase

\begin{tabular}{|c|c|c|c|}
\hline No & Use Case & Aktor & Deskripsi \\
\hline 1 & Login & $\begin{array}{l}\text { Admin } \\
\text { dan } \\
\text { Pengguna }\end{array}$ & $\begin{array}{l}\text { Merupakan proses untuk masuk } \\
\text { kedalam sistem menggunakan } \\
\text { username dan password yang } \\
\text { sudah didaftarkan }\end{array}$ \\
\hline 2 & $\begin{array}{l}\text { Kelola } \\
\text { data } \\
\text { alternatif }\end{array}$ & Admin & $\begin{array}{l}\text { Merupakan proses untuk } \\
\text { menambahkan data, mengubah, } \\
\text { menghapus, dan mencari data } \\
\text { alternatif }\end{array}$ \\
\hline 3 & $\begin{array}{l}\text { Kelola } \\
\text { data } \\
\text { kriteria }\end{array}$ & Admin & $\begin{array}{l}\text { Merupakan proses untuk } \\
\text { menambahkan data kriteria, } \\
\text { mengubah, menghapus, dan } \\
\text { proses bobot kriteria }\end{array}$ \\
\hline 4 & $\begin{array}{l}\text { Proses } \\
\text { Metode } \\
\text { TOPSIS }\end{array}$ & Admin & $\begin{array}{l}\text { Merupakan proses untuk Metode } \\
\text { TOPSIS }\end{array}$ \\
\hline 5 & $\begin{array}{l}\text { Proses } \\
\text { Metode } \\
\text { MAUT }\end{array}$ & Admin & $\begin{array}{l}\text { Merupakan proses untuk Metode } \\
\text { MAUT }\end{array}$ \\
\hline 6 & Proses & Admin & $\begin{array}{l}\text { Merupakan proses dari kedua } \\
\text { metode tersebut }\end{array}$ \\
\hline 7 & Cetak & $\begin{array}{l}\text { Admin } \\
\text { dan } \\
\text { Pengguna }\end{array}$ & $\begin{array}{l}\text { Merupakan proses untuk } \\
\text { mencetak laporan }\end{array}$ \\
\hline 8 & $\begin{array}{l}\text { Chating } \\
\text { Group }\end{array}$ & $\begin{array}{l}\text { Admin } \\
\text { dan } \\
\text { Pengguna }\end{array}$ & $\begin{array}{l}\text { Merupakan proses untuk } \\
\text { berkomunikasi sesama pengguna } \\
\text { sistem }\end{array}$ \\
\hline 9 & $\begin{array}{l}\text { Kelola } \\
\text { data } \\
\text { petugas }\end{array}$ & Admin & $\begin{array}{l}\text { Merupakan proses untuk } \\
\text { menambahkan, mengubah dan } \\
\text { menghapus data petugas }\end{array}$ \\
\hline 10 & Logout & Admin & $\begin{array}{l}\text { Merupakan proses untuk keluar } \\
\text { dari sistem }\end{array}$ \\
\hline
\end{tabular}

C. Usecase Diagram 


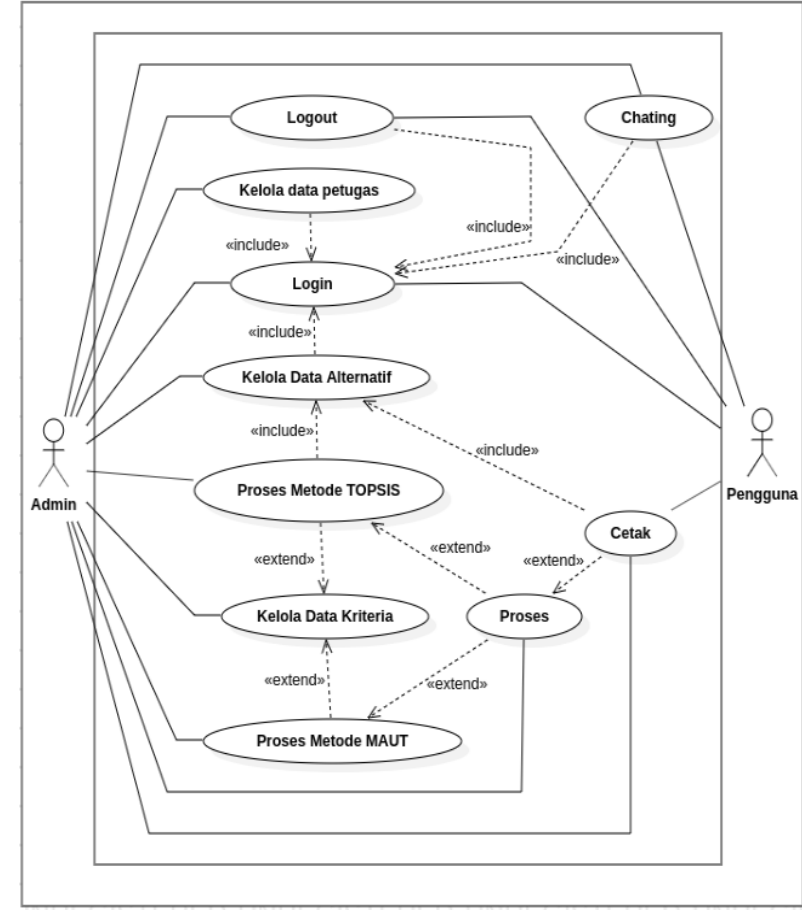

Gambar 3.2 UseCase Diagram

\section{Class Diagram (Class Definition dan Class Relation)}

\section{Class Diagram}

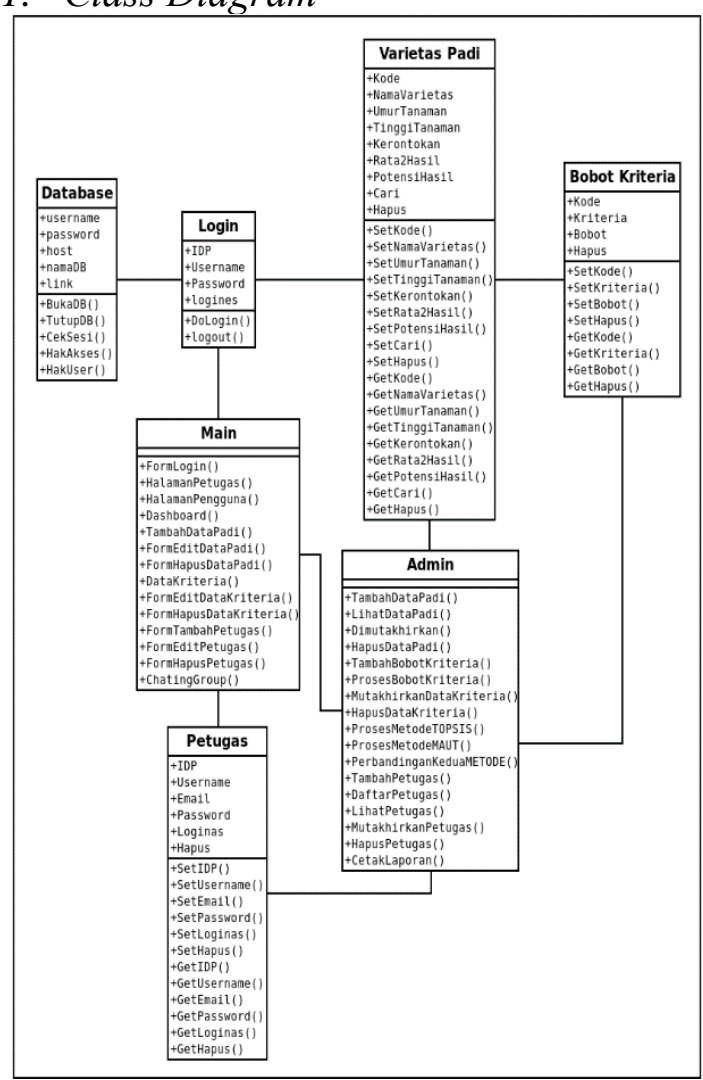

Gambar 3.3 Class Diagram
Tabel 4.16 Class Definition

\begin{tabular}{|c|c|c|}
\hline No & $\begin{array}{l}\text { Nama } \\
\text { Class }\end{array}$ & Deskripsi \\
\hline 1 & Database & $\begin{array}{l}\text { Merupakan kelas yang menghubungkan data dan } \\
\text { menampilkan halaman }\end{array}$ \\
\hline 2 & Login & $\begin{array}{l}\text { Merupakan kelas yang mempunyai metode utama } \\
\text { dari fungsi program }\end{array}$ \\
\hline 3 & Main & Merupakan kelas untuk masuk kedalam sistem \\
\hline 4 & Petugas & $\begin{array}{l}\text { Merupakan kelas untuk kelola data petugas dan } \\
\text { pengguna }\end{array}$ \\
\hline 5 & $\begin{array}{l}\text { Varietas } \\
\text { Padi }\end{array}$ & Merupakan kelas untuk kelola data alternatif \\
\hline 6 & $\begin{array}{l}\text { Bobot } \\
\text { Kriteria }\end{array}$ & Merupakan kelas untuk kelola data bobot kriteria \\
\hline 7 & Admin & Merupakan kelas untuk validasi saat waktu login \\
\hline
\end{tabular}

E. Sequence Diagram Alternatif

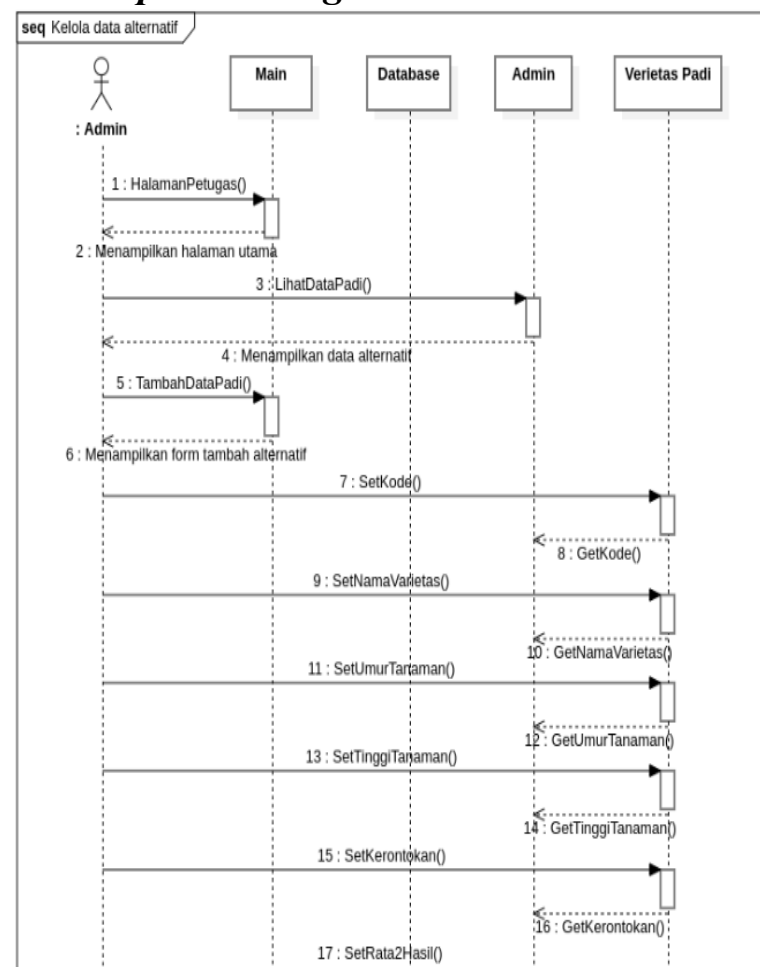

Gambar 3.4 Sequence Diagram Alternatif

\section{Class Definition}

Jurnal Interkom: Jurnal Publikasi Ilmiah Bidang Teknologi Informasi dan Komunikasi

Volume 16 Nomor 03 Bulan Oktober - Tahun 2021 


\section{F. Activity Diagram Alternatif}

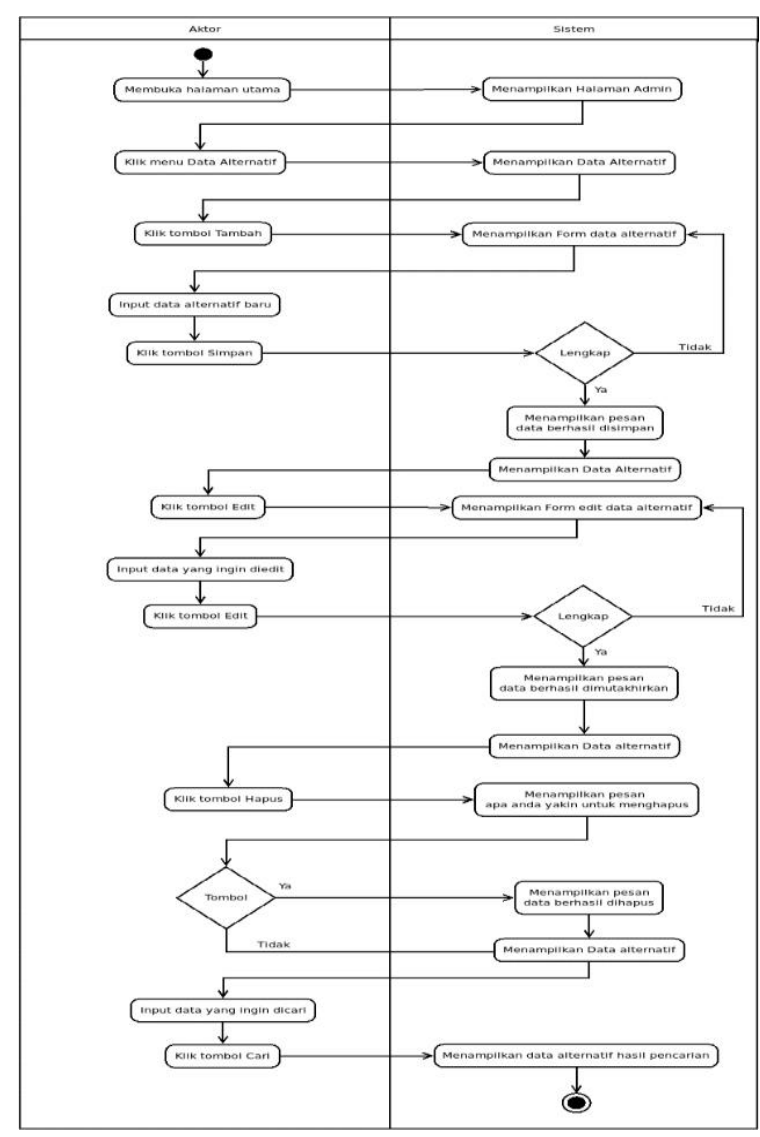

Gambar 3.5 Activity Diagram Alternatif

\subsubsection{Design Antarmuka (Input/Output)}

A. Desain Antarmuka Masukan(Input)

1. Form Input Alternatif

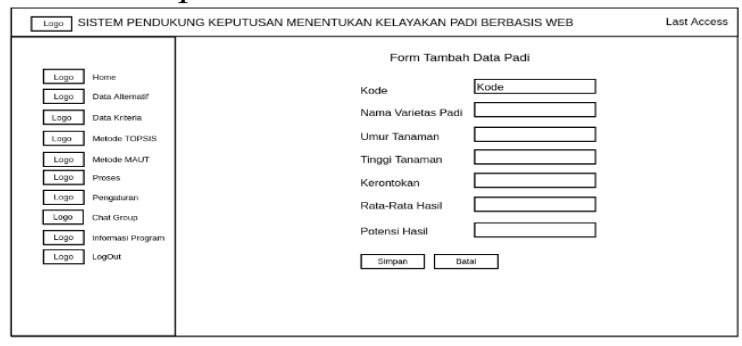

Gambar 3.6 Form Input Alternatif

\section{B. Desain Antarmuka Keluaran(Output)}

1. Form Output Alternatif

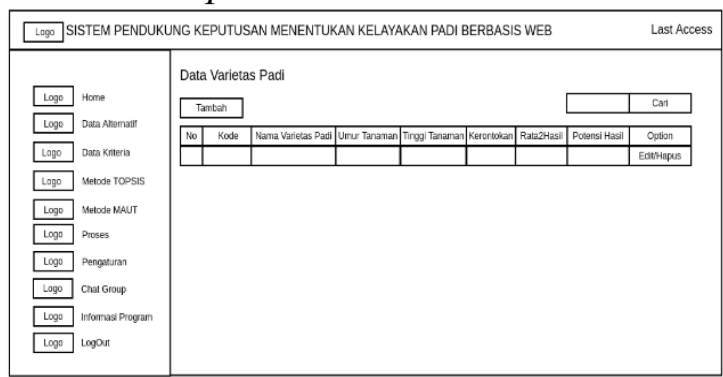

4.4. Construction of Prototype (Pembentukan Prototype)

\subsubsection{Desain Proses \\ (Algoritme} Pemrosesan Data)

Berikut ini adalah rancangan desain proses berupa flowchart yang menggambarkan sistem :

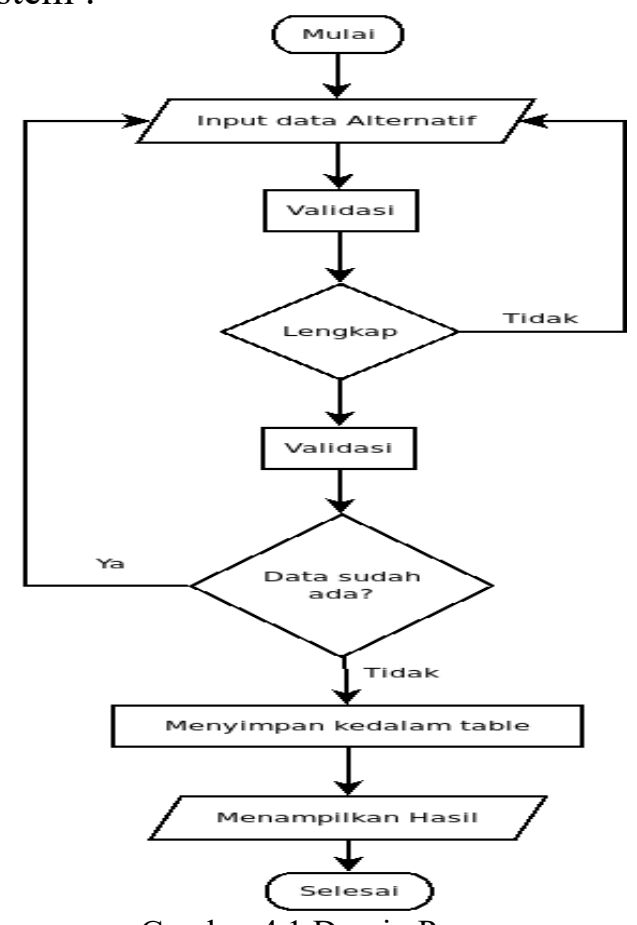

Gambar 4.1 Desain Proses

4.5. Deployment, Delivery and Feedback (Penyerahan Sistem, Pengiriman dan Umpan Balik)

\subsubsection{Spesifikasi}

kebutuhan implementasi sistem.

Terdapat tiga hal yang harus diperhatikan dalam tahap implementasi sistem yang dibuat, meliputi:

\section{A. Spesifikasi kebutuhan perangkat keras(hardware)}

Tabel 4.17 Spesifikasi kebutuhan perangkat keras

\begin{tabular}{ll}
\multicolumn{1}{c}{ Kebutuhan } & \multicolumn{1}{c}{ Spesifikasi } \\
\hline Processor & $1.80 \mathrm{GHz}(4 \mathrm{CPUs}),-1.8 \mathrm{GHz}$ \\
RAM & $4 \mathrm{~GB}$ \\
Hardisk & $500 \mathrm{~GB}$ \\
Monitor & Standar \\
Keyboard & Standar \\
Mouse & Standar \\
\hline
\end{tabular}

Gambat 3.7 Form Output Alternatif

Jurnal Interkom: Jurnal Publikasi Ilmiah Bidang Teknologi Informasi dan Komunikasi

Volume 16 Nomor 03 Bulan Oktober - Tahun 2021 


\section{B. Spesifikasi kebutuhan perangkat lunak(software)}

Tabel 4.18 Spesifikasi kebutuhan perangkat lunak

\begin{tabular}{ll}
\hline \multicolumn{1}{c}{ Kebutuhan } & \multicolumn{1}{c}{ Spesifikasi } \\
\hline Sistem Operasi & Windows, Linux \\
Server web & Apache2HTTP Server \\
Server php & PHP 7.2 \\
Server database & MySQL Server 5.7 \\
Peramban web & Mozilla Firefox dan Google Chrome \\
\hline
\end{tabular}

\section{Spesifikasi kebutuhan pengguna (user)}

Untuk kebutuhan pengguna (Admin) Petugas yaitu minimal sudah bisa menggunakan komputer (dengan sistem operasi Windows atau Linux) dan dapat mempergunakan peramban web (web browser).

\subsubsection{Pengujian Sistem}

\section{A. Pengujian White Box}

White Box Testing merupakan pengujian yang memperhitungkan mekanisme internal sistem atau komponen.

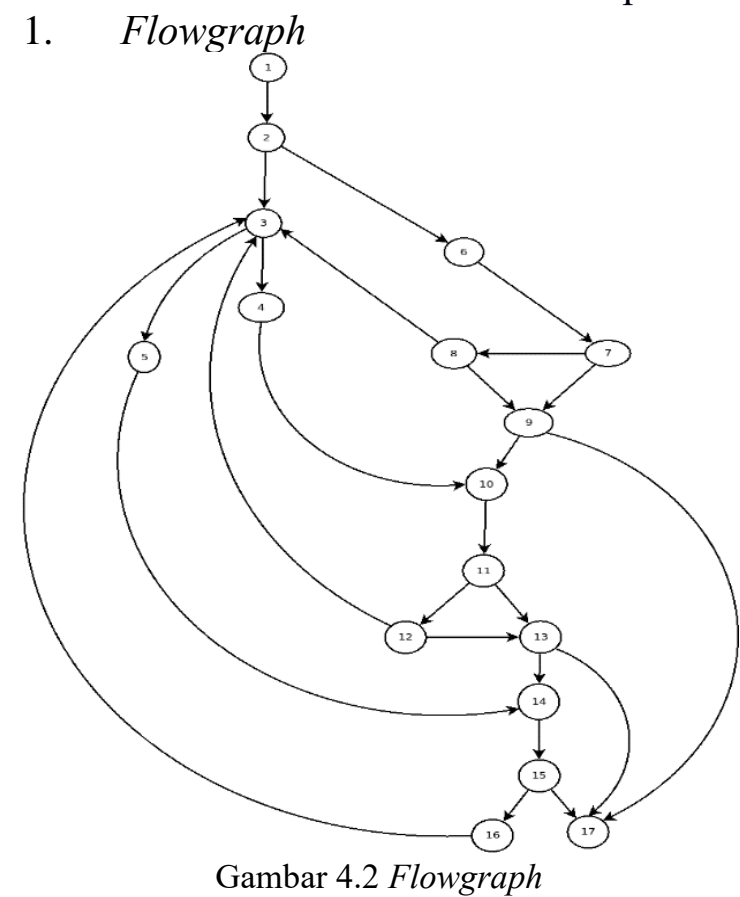

2. Cyclomatic Complexity V(G) Menyimpan data Alternatif Perhitungan ini digunakan untuk menentukan jumlah independent path yang akan ditelusuri:

$$
\begin{aligned}
\mathrm{V}(\mathrm{G}) & =\mathrm{E}(\text { edge }(\text { sisi }))-\mathrm{N}(\text { Node Simpul })+2 \\
& =25-17+2 \\
& =10
\end{aligned}
$$

\begin{tabular}{cll}
\multicolumn{3}{c}{ Tabel 4.19 E(edge(sisi) } \\
\hline No & \multicolumn{1}{c}{ Path } & \multicolumn{1}{c}{ E (edge (sisi)) } \\
\hline 1 & $1-2$ & 1 \\
2 & $2-3 ; 2-6$ & 2 \\
3 & $3-4 ; 3-5 ;$ & 2 \\
4 & $4-10$ & 1 \\
5 & $5-14$ & 1 \\
6 & $6-7 ;$ & 1 \\
7 & $7-8 ; 7-9 ;$ & 2 \\
8 & $8-3 ; 8-9 ;$ & 2 \\
9 & $9-10 ; 9-17 ;$ & 2 \\
10 & $10-11$ & 1 \\
11 & $11-12 ; 11-13 ;$ & 2 \\
12 & $12-3 ; 12-13 ;$ & 2 \\
13 & $13-14 ; 13-17 ;$ & 2 \\
14 & $14-15$ & 1 \\
15 & $15-16 ; 15-17 ;$ & 2 \\
16 & $16-3 \quad$ Total E (edge (sisi)) $=\mathbf{2 5}$ \\
\hline \multicolumn{2}{c}{}
\end{tabular}

$\mathrm{V}(\mathrm{G})=\mathrm{P}$ (Jumlah keputusan yang terkandung dalam grafik yang diwakili oleh node yang memiliki lebih dari satu sisi) +1

$$
\begin{aligned}
& =9+1 \\
& =10
\end{aligned}
$$

Tabel 4.20 jumlah keputusan dalam grafik

\begin{tabular}{cclc}
\hline No & Node (simpul) & Percabangan & $\begin{array}{c}\text { Jumlah } \\
\text { Keputusan }\end{array}$ \\
\hline 1 & 2 & $3-6$ & 1 \\
2 & 3 & $4-5$ & 1 \\
3 & 7 & $8-9$ & 1 \\
4 & 8 & $3-9$ & 1 \\
5 & 9 & $10-17$ & 1 \\
6 & 11 & $12-13$ & 1 \\
7 & 12 & $3-13$ & 1 \\
8 & 13 & $14-17$ & 1 \\
9 & 15 & $16-17$ & 1 \\
\hline \multicolumn{3}{c}{ Total Keputusan = 9 } \\
\hline
\end{tabular}

3. Independent Path (Jalur yang tidak tergantung dengan jalur yang lain) kelola data Alternatif

\begin{tabular}{ll}
\multicolumn{2}{c}{ Tabel 4.21 Hasil Penelusuran independent path } \\
\hline No & \multicolumn{1}{c}{ Path } \\
\hline 1 & $1-2-3-4-10-11-13-14-15-16$ \\
2 & $1-2-3-4-10-11-12-13-14-15-16$ \\
3 & $1-2-3-5-14-15-16$ \\
4 & $1-2-6-7-9-10-11-13-14-15-16$ \\
5 & $1-2-6-7-9-10-11-12-13-14-15-16$
\end{tabular}




\begin{tabular}{cc}
\hline No & Path \\
\hline 6 & $1-2-6-7-8-9-10-11-13-14-15-16$ \\
7 & $1-2-6-7-8-9-10-11-12-13-14-15-16$ \\
\hline
\end{tabular}

\section{B. Pengujian Black Box}

Pengujian penerimaan pengguna yaitu pengujian aplikasi secara black box yang dilakukan oleh user, yang terdiri dari sebelas kriteria yaitu akurat, kemampuan adaptasi, kecukupan, appeal, ketersediaan, kemudahan pengguna, face validity, performance, keandalan, robustness, pengujian operasional.

\section{Penutup}

\subsection{Kesimpulan}

Berdasarkan hasil perancangan, implementasi dan pengujian sistem, kesimpulan yang didapat adalah sebagai berikut:

1. Metode TOPSIS dan MAUT bisa diterapkan didalam sistem pendukung keputusan pada pemilihan varietas padi terbaik. Kedua metode ini akan dibandingkan sehingga menghasilkan alternatif terbaik untuk dijadikan sebagai pengambilan keputusan akhir dan dari hasil pengujian yang dilakukan, akurasi kecocokan antara kedua metode tersebut dalam penelitian varietas padi ini.

2. Hasil dari penelitian ini memperoleh varietas padi yang berkualitas pada metode TOPSIS dan MAUT:

- Super : Silugonggo, Cibodas, Cimalaya, Sunggal, Maro, Hipa 3.

- Sedang : Digal, Batang Gadis, Angke, Rokan.

- Rendah : Tuket Petuna, Cisadane, Hipa 4.

\subsection{Saran}

Saran yang diberikan untuk pengembangan sistem dalam penelitian selanjutnya:

1. Meski bisa dibilang cukup layak namun hasil akhir dari sistem masih secara umum, belum secara spesifik memperhitungkan faktor-faktor lain yang bisa jadi sangat berpengaruh pada varietas padi tersebut seperti contohnya faktor umur tanaman, tinggi tanaman, kerontokan, rata-rata hasil dan potensi hasil. 5 Kriteria yang digunakan didalam sistem dinilai masih belum maksimal untuk dijadikan kriteria dalam pengambilan keputusan akhir.

2. Aplikasi yang dibuat diharapkan dapat dikembangkan menggunakan metode lainnya dan menggunakan data yang lebih banyak lagi serta menggunakan program aplikasi berbasis android.

\section{Daftar Pustaka}

[1] Agus. 2014. Padi (Oryza sativa). http://www.ristek.go.id. Diakases pada tangga 19 September 2014.

[2] D. Adittia, N. Hidayat, and F. A. Bachtiar, "Penerapan Metode Analitycal Hierarchy Process-Simple Additive Weighting ( AHP-SAW ) dalam Penentuan Varietas Padi yang Unggul," J. Pengemb. Teknol. Inf. dan Ilmu Komput. Univ. Brawijaya, vol. 2, no. 11, pp. 5333-5339, 2018.

[3] Enterprise J, 2014. MySQL untuk Pemula. Jakarta: PT. Elex Media Komputindo.

[4] Hirin., Virgi. 2011. Cepat Mahir Pemrograman Web Dengan PHP Dan MySQL.

Penerbit Prestasi Pustaka, Jakarta ISBN:978-602-8963-09-1

[5] Jogiyanto. 2005. Analisis dan Desain Sistem Informasi Pendekatan Terstruktur Edisi III, Yogyakarta. Andi Offset ISBN:979-731-560-6

[6] Kusuma, D. (2008). Informasi Tentang Sistem Pakar. Jakarta: Balai Pustaka

[7] Kusuma, D. (2008). Informasi Tentang Sistem Pakar. Jakarta: Balai Pustaka

[8] Rifai, Ahmad., Sunandar, Hery. 2016. Aplikasi Kriptografi Database MySQL Menggunakan Metode Markel Helman, Medan. ISSN : 2548-6985 
[9] Roger S. Pressman, 2010, Software Engineering A Practitioner's Apporach Sevent

Edition. Mc Graw Hill Higher Education. ISBN 0-07-365578-3

[10] Sachdeva. Diana Fatmawati, Sultoni, "Sistem Pengambilana Keputusan Kelayakan Bagi Calon Penerima Dana Bantuan Masyarakat Miskin Menggunakan Metode TOPSIS Berbasis WEB," J. Inform. Merdeka Pasuruan, vol. 1, no. 1, pp. 1-11, 2016.

[11] W. Yahyan and M. I. A. Siregar, "Sistem Pendukung Keputusan Pemilihan Bibit Benih Padi Unggul Berbasis Web Menggunakan Metode AHP (Analytical Hierarchy Process)," Menara Ilmu, vol. XIII, no. 11, pp. 110 123, 2019,

[12] Scott, J. Ho, W. Dey P. K., Talluri S. 2014. A Decision Support System for Supplier Selection and Order Allocation in Stochastic, Multi-Stakeholder and Multi-Criteria Environments. Elsevier.

[13] Tata Sutabri. 2012. Analisis Sistem Informasi. Andi. Yogyakarta

[14] Yakub, 2012. Pengantar Sistem informasi: Grahallmu. Yogyakarta. 